\title{
Pemeriksaan Kolesterol , LDL, dan HDL Daging Ayam Petelur Jantan dengan Pakan Berimbuhan Serbuk Daun Kelor
}

\section{Cholesterol, LDL, and HDL Examination of Male Layer Chicken with Moringa Leaf Powder Feed}

\author{
Muhammad Anwar Djaelani*, Kasiyati, Sunarno \\ Program Studi Biologi, Fakultas Sains dan Matematika, Universitas Diponegoro, Semarang \\ *Email : muhammadanwardjaelani@ rocketmail.com
}

Diterima 25 November 2019 / Disetujui 25 Februari 2021

\begin{abstract}
ABSTRAK
Penelitian ini dirancang untuk melihat pengaruh tepung daun kelor sebagai imbuhan pakan terhadap kadar kolesterol total, kadar LDL dan kadar HDL daging ayam petelur jantan. Penelitian ini bertujuan menganalisis perubahan fisiologis yang terjadi pada profil lipid daging ayam petelur jantan terkait dengan pemberian tepung daun kelor sebagai imbuhan pakan. Penelitian menggunakan Rancangan Acak Lengkap dengan lima perlakuan, terdiri atas satu perlakuan kelompok kontrol dan empat kelompok perlakuan dengan pakan basal yang diberi imbuhan berbagai kadar tepung daun kelor. Kelompok perlakuan pada penelitian ini adalah K0: Pakan basal, tanpa imbuhan tepung daun kelor (kontrol) K1: Pakan basal yang diberi imbuhan tepung daun kelor 1\% K2: Pakan basal yang diberi imbuhan tepung daun kelor 2\% K3: Pakan basal yang diberi imbuhan tepung daun kelor 3\% K4: Pakan basal yang diberi imbuhan tepung daun kelor 4\%.Variabel yang diamati adalah kadar kolesterol total daging, LDL daging, serta HDL daging ayam petelur jantan. Analisis data dilakukan dengan Anova Hasil penelitian menunjukkan terdapat penurunan yang nyata kadar kolesterol total daging dan kadar LDL daging, serta peningkatan kadar HDL daging ayam yang nyata $(P<0.05)$.Pada penelitian ini dapat disimpulkan bahwa pemberian tepung daun kelor sebagai imbuhan pakan berpotensi memperbaiki performa lipid daging ayam
\end{abstract}

Kata kunci : kolesterol, $L D L, H D L$

\begin{abstract}
This study was designed to know the effect of moringa leaf flour as a feed additive to total cholesterol, LDL levels and HDL levels of male laying hens. This study aims to analyze the physiological changes that occur in the lipid profile of male laying hens associated with giving Moringa leaf flour as feed additives. The study used a Completely Randomized Design with five treatments, consisting of one control group treatment and four treatment groups with basal feed which were added with various levels of Moringa leaf flour. The treatment group in this study was K0: Basal feed, without added Moringa leaf flour (control) K1: Basal feed which was added with Moringa leaf flour 1\% K2: Basal feed which was added with Moringa leaf flour 2\% K3: Basal feed which was added Moringa leaf flour 3\% K4: Basal feed which is added with 4\% Moringa leaf flour. The observed variables are total cholesterol level of meat, LDL of meat, and HDL of laying hens. Data analysis was performed with Anova. The results showed a significant decrease in total cholesterol levels in meat and LDL levels in meat, as well as an increase in HDL levels in chicken meat significantly $(\mathrm{P}<0.05)$. chicken lipid performance
\end{abstract}

Keywords: cholesterol, $L D L, H D L$ 


\section{PENDAHULUAN}

Ayam merupakan sumber protein hewani yang digemari masyarakat Ayam merupakan komoditas dengan nilai ekonomi yang potensial. (Tana dan Djaelani, 2015). Konsumsi daging nasional berasal dari unggas berkisar $70 \%$. (Widiati, 2014) Penggemar masakan berbahan dasar ayam mulai menghindari ayam broiler dengan alasan kandungan lemak yang tinggi. (Tana dan Djaelani, 2015). Akhir-akhir ini mulai banyak peternak unggas memelihara ayam petelur jantan yang merupakan hasil ikutan penetasan ayam petelur komersial impor dengan tujuan untuk menghasilkan daging. Telah banyak rumah makan yang menjadikan ayam petelur jantan sebagai salah satu menu utamanya. Cita rasa ayam jantan yang hampir mirip dengan ayam kampung telah membantu mencukupi permintaan akan daging ayam kampung yang kian hari kian sulit didapat (Nita et al., 2015). Kandungan kolesterol daging ayam jantan lebih tinggi dibanding dengan kandungan kolesterol daging ayam betina (Saidin,2000).

Berbagai jenis tanaman herbal telah dieksplorasi dalam rangka meningkatkan fungsionalitas organ. Salah satu jenis tanaman herbal yang telah lama dikenal di Indonesia sebagai sayur dan pakan ternak adalah tanaman kelor (Moringa oleifera Lam.). Daun kelor (Moringa oleifera Lam.) merupakan salah satu herbal dengan kandungan nutrisi tinggi dan sering dipergunakan sebagai sumber bahan pangan lokal. Daun kelor berpotensi tinggi sebagai antioksidan, antibanteri patogen, antipiretik, antitumor, antiepilepsi, antiinflamasi, antiulser, antihipertensi, diuretik, hipokolesterolemia, stimulan jantung dan peredaran darah (Toripah et al. 2014).

Analisis fitokimia daun kelor menunjukkan adanya kandungan gula sederhana, rhamnose, glukosinolat dan isotiotianat (Soetanto, 2005). Penambahan daun kelor pada pakan menunjukkan peningkatan konsumsi pakan, pertambahan bobot hidup, konversi pakan, serta berat karkas. ayam pedaging (Sjofjan, 2008). Pemberian tepung daun kelor sebagai imbuhan pakan ayam petelur meningkatkan bobot telur, skor warna kuning telur, serta menurunkan kandungan kolesterol telur. Penambahan daun kelor pada pakan tidak menyebabkan peningkatan produksi telur (HDP: hen day production) (Satria et al., 2016). Penggunaan tepung daun kelor sebagai imbuhan pakan dalam memperbaiki performa lipid daging ayam masih terbatas sehingga sangat penting dilakukan penelitian untuk melihat secara keseluruhan pengaruh tepung daun kelor pada performa lipid daging ayam pedaging.

\section{METODE PENELITIAN}

Materi penelitian yang digunakan adalah ayam ras petelur jantan strain Isa Brown dari PT Charoen Pokphand, sebanyak 100 ekor berumur tiga hari. Ayam tersebut ditempatkan ke dalam 25 buah petak kandang Masing-masing petak kandang berisi empat ekor ayam setiap ekor ayam. Kandang penelitian sistem litter dengan alas sekam padi dicampur kalsit, kandang berukuran 100x150x70 $\mathrm{cm}^{3}$ DOC ayam ras petelur jantan ditempatkan pada kandang perlakuan sesuai dengan pengacakan kandang.

temperatur kandang berkisar $28-34^{\circ} \mathrm{C}$, pakan dan minum disediakan ad libitum. Pakan ayam yang digunakan selama penelitian telah disesuaikan dengan kebutuhan nutrisi ayam petelur. Ransum yang digunakan pada penelitian ini adalah ransum komersial broiler fase starter dan finisher, dengan kandungan protein $21-23 \%$, serat $4 \%$, lemak $4 \%$, air, $14 \%$, abu, $6,5 \%$ kalsium $0,9-1,1 \%$, posfor $0,7-$ 0,9\% dan energi metabolisme $2800-3000 \mathrm{kkal} / \mathrm{kg}$ ransum. Tepung daun kelor diperoleh dari PT Moringa Organik Indonesia, Blora, Jawa Tengah.

Rancangan yang digunakan pada penelitian ini adalah Rancangan Acak Lengkap dengan lima perlakuan. Masing-masing perlakuan terdiri atas lima ulangan kandang, setiap ulangan berisi empat ekor ayam petelur jantan. Menurut Satria et al. (2016), imbuhan tepung daun kelor $2 \%$ pada pakan dapat meningkatkan produksi dan kualitas telur ayam. Berdasar penelitian tersebut maka pakan perlakuan disusun sebagai berikut,

K0: Pakan basal, tanpa imbuhan tepung daun kelor (kontrol)

K1: Pakan basal yang diberi imbuhan tepung daun kelor $1 \%$ 
K2: Pakan basal yang diberi imbuhan tepung daun kelor $2 \%$

K3: Pakan basal yang diberi imbuhan tepung daun kelor 3\%

K4: Pakan basal yang diberi imbuhan tepung daun kelor $4 \%$

Penyembelihan ayam dilakukan dengan metode Kosher dengan memotong batang tenggorokan (trachea), pembuluh balik leher (vena jugularis), pembuluh nadi leher (arterikarotis), dan kerongkongan (esophagus) secara bersamaan, setelah ayam mati, selanjutnya ayam dicelupkan ke dalam air panas dengan suhu 50-54 ${ }^{\circ} \mathrm{C}$ selama 30-50 detik (Soeparno,2005). Tahap berikutnya dilakukan pemrosesan yang terdiri atas pencabutan bulu dan Isolasi daging. Data yang diperoleh dianalisis dengan Anova dilanjutkan dengan uji Duncan. Beda nyata dievaluasi pada taraf $P<0.05$.. Semua analisis data dikerjakan dengan SPSS versi 23 (Santoso, 2018).

\section{HASIL DAN PEMBAHASAN}

Kondisi lingkungan yang diamati selama penelitian yaitu meliputi suhu dan kelembaban relatif lingkungan perkandangan. Secara keseluruhan suhu dan kelembaban lingkungan kandang adalah berkisar $27 \mathrm{oC}-29 \mathrm{oC}$ dan $70 \%$ $76 \%$. Semua kandang penelitian kisaran suhu dan kelembabannya sama, sehingga jika terdapat perbedaan nilai variable bukan disebabkan faktor lingkungan tetapi disebabkan karena perlakuan penelitian. Hasil analisis data penelitian terhadap data kolesterol total daging, LDL daging dan HDL daging pada ayam setelah pemberian pakan dengan imbuhan tepung kelor disajikan pada Tabel 1 .

Tabel 1. Rata-rata kolesterol total, LDL dan, HDL pada ayam setelah pemberian pakan dengan imbuhan tepung kelor

\begin{tabular}{cccc}
\hline & Kolesterol $(\mathbf{m g} / \mathbf{d l})$ & LDL $(\mathbf{m g} / \mathbf{d l})$ & HDL $\mathbf{( m g} / \mathbf{d l})$ \\
\hline K0 & $113,50^{\mathrm{a}} \pm 3,36$ & $41,59^{\mathrm{p}} \pm 4,36$ & $9,31^{\mathrm{a}} \pm 4,42$ \\
K1 & $94,4^{\mathrm{b}} \pm 3,28$ & $55,54^{\mathrm{q}} \pm 2,48$ & $10,36^{\mathrm{b}} \pm 3,62$ \\
K2 & $81,00^{\mathrm{c}} \pm 3,80$ & $64,98^{\mathrm{r}} \pm 2,89$ & $11,59^{\mathrm{c}} \pm 2,57$ \\
K3 & $72,00^{\mathrm{d}} \pm 5,07$ & $75,26^{\mathrm{s}} \pm 2,07$ & $12,83^{\mathrm{d}} \pm 3,80$ \\
K4 & $70,00^{\mathrm{d}} \pm 6,20$ & $80,3^{\mathrm{s}} \pm 3,07$ & $14,09^{\mathrm{e}} \pm 2,90$ \\
\hline
\end{tabular}

Keterangan: Superskrip yang berbeda pada kolom yang sama menunjukkan perbedaan yang nyata antar perlakuan. $\mathrm{K} 0=$ kelompok kontrol, kelompok ayam dengan pakan tanpa tambahan tepung kelor. $\mathrm{K} 1=$ kelompok kelompok ayam pakan dengan tambahan tepung kelor $1 \% . \mathrm{K} 2=$ kelompok kelompok ayam pakan dengan tambahan tepung kelor $2 \%$. K3 = kelompok kelompok ayam pakan dengan tambahan tepung kelor 3\%. K4 = kelompok ayam pakan dengan tambahan tepung kelor $4 \%$

Hasil penelitian seperti tampak pada Tabel 1, menunjukkan bahwa setelah pemberian pakan dengan penambahan tepung kelor pada konsentrasi yang semakin meningkat pada setiap perlakuan berakibat semakin menurunnya kadar kolesterol dan LDL dibandingkan dengan kontrol (tanpa imbuhan tepung kelor). Penambahan tepung kelor dengan konsentrasi yang semakin meningkat pada setiap perlakuan berakibat semakin meningkatnya HDL kolesterol dibandingkan dengan kontrol. Menurut Soeharto, (2014) kolesterol merupakan lemak kompleks yang dihasilkan oleh tubuh dengan tujuan berbagai fungsi. Kolesterol disintesis di dalam hepar, kolesterol merupakan komponen utama struktur semua membran sel. Kolesterol disamping merupakan bahan baku struktur sel juga merupakan bahan dasar pembentukan komponen beberapa hormon seperti hormon adrenalin, hormon estrogen, dan hormon testosterone. Kolesterol juga merupakan bahan penting penyusun vitamin $\mathrm{D}$ dan asam empedu .

Sintesis kolesterol dalam tubuh dimulai satu molekul asetil CoA dan satu molekul asetoasetilCoA, terhidrasi membentuk 3-hidroksi-3metilglutaril CoA (HMG-CoA). Molekul tersebut kemudian direduksi menjadi mevalonat oleh enzim HMG-CoA reduktase. Mevalonat merupakan bahan dasar untuk biosintesis berbagai molekul, 
termasuk kolesterol. Pengaturan pembatasan laju sintesis kolesterol dapat terjadi adanya aksi dari statin yang merupakan penghambat kompetitif HMG-CoA reduktase. Laju produksi kolesterol relatif bervariasi sesuai tipe sel dan fungsi organ. Semua sel hewan memproduksi kolesterol berkisar 20-25\% dari total produksi kolesterol harian berada pada hepar (Berg,2002).

Low-density lipoprotein (LDL) dan Highdensity lipoprotein (HDL) merupakan kelompok lipoprotein. Masyarakat sering menyebut LDL sebagai kolesterol jahat karena dapat mengendapkan lemak pada dinding arteri serta menarik makrofag dan menyebabkan aterosklerosis. Masyarakat sering menyebut. HDL sebagai kolesterol baik atau kolesterol sehat karena dapat memisahkan molekul lemak dari makrofag pada dinding arteri (Toth, 2005). Melalui cairan ekstra sel lipoprotein mengedarkan lemak keseluruh tubuh dan masuk ke dalam sel melalui receptor-mediated endocytosis. (Dashti, 2011); (Dashty, 2014). Kolesterol yang telah disintesis akan berikatan dengan LDL reseptor kemudian ditranspor menuju sel hepar, yang kemudian digunakan untuk sintesis asam empedu (Liscum, 2002). HDL memindahkan partikel lemak melalui reseptor HDL yaitu scavenger receptor BI (SR$\mathrm{BI}$ ), yang memperantarai penarikan kolesterol dari HDL (Huang, 2013). Peningkatan kolesterol pada sel terjadi karena penyerapan lipoprotein yang mengandung kolesterol oleh reseptor (Kathleen et al., 2006).

Menurut Wirahadikusumah (1985), HDL berfungsi mengangkut kelebihan kolesterol dalam bentuk LDL ditranspor melalui pembuluh darah. Kandungan kolesterol daging pada kelompok perlakuan lebih rendah dibanding kandungan kolesterol daging pada kelompok kontrol. Hal tersebut diduga karena antioksidan dalam tepung daun kelor (Moringa ofeifera) menyebabkan konversi kolesterol menjadi asam empedu dalam tubuh meningkat, hal tersebut mengakibatkan absorbsi kolesterol di jejunum sedikit sehingga kadar kolesterol daging menurun. Salah satu komponen dalam kelor yaitu betasitosterol merupakan senyawa sterol yang dapat menurunkan kolesterol. Struktur Beta-Sitosterol mirip dengan kolesterol, sehingga dapat memblokir penyerapan kolesterol dari makanan (Kurniasih,2012).

Berdasarkan hal tersebut maka dapat dipahami jika kadar kolesterol dan LDL pada daging ayam kelompok perlakuan lebih rendah dibanding kelompok kontrol dan kadar HDL pada daging ayam kelompok perlakuan lebih tinggi dibanding kelompok kontrol.

\section{KESIMPULAN}

Berdasarkan hasil penelitian dapat disimpulkan pemberian tepung daun kelor hingga dosis $3 \%$ berpotensi memperbaiki performa lipid daging ayam melalui penurunan kolesterol total, LDL serta meningkatkan HDL daging ayam

\section{DAFTAR PUSTAKA}

Berg, J. 2002. Biochemistry. WH Freeman. New York

Chivapat S., P. Sincharoenpokai, P. Suppajariyawat, A. Rungsipipat, S. Phattarapornchaiwat, V. Chantarateptawan. 2012. Safety evaluation of ethanolic extract of Moringa oleifera Lam. Seed in experimental animals. Thai. J. Vet. Med. 42(3): 343-352.

Dashti, M., Kulik W., Hoek F., Veerman E.C., Peppelenbosch M.P., Rezaee F. 2011. A phospholipidomic analysis of all defined human plasma lipoproteins. Sci Rep. 1 (139).

Dashty, M., Motazacker M.M., Levels J, de Vries M., Mahmoudi M., Peppelenbosch M.P., Rezaee F. 2014. Proteome of human plasma very low-density lipoprotein and lowdensity lipoprotein exhibits a link with coagulation and lipid metabolism. Thromb Haemost. 23 (111): 518-530.

Daud M., Zahrul F. dan Mulyadi 2017 Performa dan Persentase Karkas Ayam Ras Petelur Jantan pada Kepadatan Kandang yang Berbeda.J Agripet: Vol (17)No. 1 : 67-74

Huang ,C.X., Zhang Y.L. 2013. The target of regulating the ATP-binding cassette A1 protein (ABCA1): promoting ABCA1mediated cholesterol efflux in different cells 
Current Pharmaceutical Biotechnology 14 (6): 623-31.

Kakengi A.M.V., M.N. Shem, S.V. Sarwatt, T. Fujihara. 2005. Can Moringa oleifera be used as protein supplementation for ruminants? Asian-Aust. J. Anim. Sci., 18(1): 42-47.

Khaled A.E.F.M., L.S. Franco, R.S. Ricalde, J.F.S. Sanchez. 2012. The nutritional effect or Moringa oleifera fresh leaves as feed supplement on Rhode Island Red hen egg production and quality. Trop. Anim. Health Prod., 44:1035-1040.

Kathleen, M. B. and P. A. Meyes. 2006. Sintesis, transpor dan ekskresi kolestrol: Biokimia Herper. Editor R. K. Murray, D. K. Granner, dan V.W. Rodwell. Penerbit Buku Kedokteran EGC. Jakarta.

Keene, D., Price, C., Shun-Shin, M.J., Francis, D.P. 2014. Effect on cardiovascular risk of high density lipoprotein targeted drug treatments niacin, fibrates, and CETP inhibitors: meta-analysis of randomised controlled trials including 117,411 patients. BMJ (Clinical research ed.) 349: g4379.

Kurniasih. 2012. Khasiat dan Manfaat Daun Kelor untuk penyembuhan berbagai penyakit.. Cetakan Pertama Pustaka Baru Press, Banguntapan, Bantul, Yogyakarta

Liscum, L. 2002. Cholsetrol biosynthesis. Biochemistry of lipids, lipoproteins and membranes. Editors D. E. Vance and J. E. Vamce. Elsevier

Makkar H.P.S., and K. Becker. 1997. Nutrients and anti-quality factors in different morfological parts of the Moringa oleifera tree. J. of Agric. Sci. Cambrige. 128: 311322.

Muhajir. 2002. Turunkan kolesterol ayam kampung dengan lisin. Poultry Indonesia.Ed.September. 68-69.

Muharlien MP, E. Sudjarwo, A.Harmiati. H. Setyo P., 2017 Ilmu Produksi Ternak Unggas Universitas Brawijaya Press hal. 21-24
Murray, Robert K., D. K. Granner, P.A. Mayes, and V. W. Rodwell. 2003. Harper'sIllustrated Biochemistry a Lange medical book. 16th ed. The McGraw-Hill Companies. United States of America. pp 219-229

Nita NS, E. Dihansih, dan Anggraeni. 2015 Pengaruh Pemberian Kadar Protein Pakan Yang Berbeda Terhadap Bobot Komponen Karkas Dan Non-Karkas Ayam Jantan Petelur J. Peternakan 1 (2) : 89-96

Rasyaf, M. 2011. Panduan Beternak Ayam Pedaging. Cetakan ke-4. Penebar Swadaya. Jakarta

Saidin,M. 2000. Kandungan Kolesterol Dalam Berbagai Bahan Makanan Hewani Buletin Penelitian Kesehatan. 27(2):224-230

Santoso,S. Panduan lengkap menguasai SPSS 16. 2008. Jakarta : PT Elex Media Komputindo, $237-248$.

Satria E.W., O. Sjofjan, I.H. Djunaidi. 2016. Respon pemberian tepung daun kelor (Moringa oleifera) pada pakan ayam petelur terhadap penampilan produksi dan kualitas telur. Buletin Peternakan. 40 (3): 197-202.

Simbolan J.M., M. Simbolan, N. Katharina. 2007. Cegah Malnutri dengan Kelor. Yogyakarta: Kanisius.

Sjofjan O. 2008. Efek penggunaan tepung daun kelor (Moringa oleifera) dalam pakan terhadap penampilan produksi ayam pedaging. Seminar Nasional Teknologi Peternakan dan Veteriner, Bogor.

Soeharto, I. 2004. Serangan Jantung dan Stroke Hubungannya dengan Lemak dan Kolesterol. Edisi ke 2. PT. Gramedia Pustaka Utama, Jakarta.

Soeparno. 2005. Ilmu dan Teknologi Daging. Gadjah Mada University Press. Yogyakarta.

Soetan, K. O., O. E. Oyewole. 2009. The need for adequate processing to reduce the antinutritional factors in plants used as human food and animal feeds:a review. African J. Food Sci., 3(9):223-232. 
Suhada S. 2016. Pengaruh Penggunaan Tepung Daun Kelor (Moringa oleifera Lamk) dan Asam Fulvat terhadap Kualitias Telur Puyuh. 2016. Skirpsi. Institut Pertanian Bogor, Bogor.

Tana S., dan M.A.Djaelani. 2015. Kadar Kolesterol Daging Ayam Broiler Setelah Pemberian Teh Kombucha. Buletin Anatomi dan Fisiologi 23(1) : 1-8

Toth ,P.P. 2005. Cardiology patient page. The "good cholesterol": high-density lipoprotein. Circulation $111 \quad$ (5): e89-e91. Tully,S,R.J.,1970 Cholesterol Requirement of Mycoplasmas Journal of Bacteriology 102 (2): 306-310

Toripah S.S., J. Abidjulu, F. Wehantouw. 2014. Aktivitas antioksidan dan kandungan total fenolik ekstrak daun kelor (Moringa oleifera Lam). Pharmacon 3(4): 37-43.

Widiati, R., A. Rahman, S. Sudaryati. 2014. "Semi Intensive Native Chicken Farming As An Alternative Establish Food Sovereignity of Rural Communities" dalam Proceeding Seminar Sustainable Livestock Production Based on LocalResources in the Global Climate Change Era : Prospect and Chalanges. Faculty of Animal Husbandry, University of Brawijaya.Malang, Indonesia.

Wirahadikusumah, M. 1985. Biokimia Metabolisme Energi, Karbohidrat dan Lipid. Bandung. ITB.

Yunike, T., S. Suharyati dan K. Nova.2014. Respon Fisiologis Ayam Jantan Tipe Medium Di Kandang Panggung Dengan Kepadatan Berbeda. Jurnal Ilmiah Peternakan Terpadu. 2 (1): 56-60 